VI. On two Aquatic Hymenoptera, one of which uses its Wings in Swimming. By Jонм LubBock, Esq., F.R.S., F.L.S., F.G.S.

\title{
(Plate XXIII.)
}

Read May 7th, 1863.

ON one of the early days in August I was enjoying myself by watching the animals in a basin of pond-water. It is customary to regard the inhabitants of fresh water as less beautiful and varied than those of the sea. But though our inland lakes and rivers can boast no Sea-anemones, no Starfishes, Medusæ, Shrimps, nor Sea-urchins, they still are full of beauty and variety. Without counting the rarer forms, almost every weedy pool contains specimens of Daphnia, Cyclops, Diaptomus, and Asellus among Crustacea, the Hydra among Polypes, the lovely green Volvox, and many other Algx, besides numerous Desmidiæ and Diatomaceæ, with Insects almost innumerable. Besides the perfect insects, such as Water-beetles, Notonecta, Nepa, and other Hemiptera, there are larvæ of Dragon-flies, Beetles, Phryganeas and Ephemeras, the beautifully transparent larvæ of Corethra and many other species of Diptera. But though most of the great orders are more or less richly represented, no aquatic species of Hymenoptera* or Orthoptera $\uparrow$ had, till now, been discovered. The species of Hyenoptera have been estimated at about 30,000 in number, and Mr. F. Smith (than whom there is no better authority) informs me that about 12,000 have been already described, 3500 of which live in Great Britain. From the interest attaching in many cases to their habits, from their marvellous instincts, and their curious relations to other animals (no order presenting more parasites and victims of parasites), the peculiarities of Hymenoptera have received more attention than those of almost any other group of Invertebrata.

Great therefore was my astonishment, on the occasion to which I allude, when I saw in the water a small Hymenopterous insect, evidently quite at its ease, and actually swimming by means of its wings. At first I could hardly believe my eyes; but having found several specimens, and shown them to some of my friends, there can be no doubt about the fact. Moreover, the same insect was again observed, within a week, by another entomologist, Mr. Duchess, of Stepney. This gentleman mentioned it to Dr. Sclater, and, from his description and sketch, there can be no doubt that the insect observed

* The female of Agriotypus armatus, indeed, has been observed to descend the sides of rocks in the Clyde to a considerable depth, and to remain there several minutes. Even this species, however, cannot be considered as truly aquatic, or as being entirely at home in the water, since there is no evidence that it knows how to swim.

Mr. Smith also reminds me that Smiera (Chalcis) femorata and S. sispes are said to be parasitic on the aquatic larvæ of Stratiomys, in which case the perfect insect probably seeks its prey under water; but I am not aware that it has been actually observed to do so.

† A "Grillon aquatique" is indeed described by Stoll ; but Westwood, in his excellent "Introduction to the Modern Classification of Insects,' expresses some doubt as to the accuracy of this statement. 
by him belongs to the same species. It is a very curious coincidence that, after remaining so long unnoticed, this little insect should thus be found, almost simultaneously, by two independent observers.

Perhaps this may, in part at least, be accounted for by supposing that the insect was unusually abundant this summer. Yet Mr. Duchess appears to have met with only one specimen. Mine were altogether twenty-one in number, and the females were more than twice as numerous as the males.

Specimens which I forwarded to my friend Mr. Walker, to whose ready kindness and valuable assistance I am much indebted, were at first considered by him to be the Polynema fuscipes of Haliday, and under this name I exhibited them at the September Meeting of the Entomological Society.

Subsequent examination, however, has shown that my insect, although allied to Polynema fuscipes, cannot be referred to that species. The males not only differ in colour, but also in the number of segments of the antennæ, which, in my specimens, as in Anaphes (the abdomen of which last is, however, subsessile), are twelve in number, while the males of Polynema fuscipes, and, indeed, of all the hitherto described species of that genus, have thirteen.

Polynema ovulorum has been bred from the eggs of the common Cabbage Butterfly, and the whole group is, in its larval state, parasitic. My specimens were no doubt in quest of some aquatic victim; but this can hardly have been their only object, for the males enter the water as readily as do the females.

The second species to which $I$ am anxious to call your attention is also very interesting, but, although apparently forming a new genus, it is in some respects less remarkable than the first. I found them in the same pond; but whereas Polynema natans swims with its wings, and uses its legs apparently only for walking, the present species, when under water, holds its wings motionless, and uses its legs as oars. Though they are neither flattened nor provided with any well-developed fringe of setæ, still they seem to serve their purpose pretty well, and the motion of this species is more rapid than that of the former.

Both species are fond of creeping along the sides of the vessel in which they are kept, or on the leaves and stems of aquatic plants ; but very frequently they quit their support, and swim boldly out into the open water.

As the motion in Polynema notans is caused by the wings, it might almost be called a flight; owing, however, to the density of the medium, and partly perhaps to the direction in which the wings act, the movement, though not inelegant, is slow, and is rather a succession of jerks than a continuous progression.

The insect is provided with tracher, and respiration appears to take place through spiracles in the usual manner. Most of those insect-larvæ which spend much of their time under water are either provided with gills, or carry down with them a supply of air attached to their body, and from which the tracher can be replenished. Our insect possesses neither of these advantages; nor can much respiration take place through the skin, which is thick and chitinous.

Moreover, it has some difficult'y in passing from air to water, or vice versâ : a bubble 
of air would quite destroy its equilibrium when under water, and a drop of water would equally prevent free motion in the air. The difficulty is, however, mitigated by the fact that the air in the trachere requires changing only at considerable intervals. A common. house-fly placed under water ceased to move in half an hour. My specimens, however, of Polynema natans lived under water several hours without suffering any apparent inconvenience. One, which I put in a bottle full of water at 7 o'clock in the morning, was quite lively at 7 o'clock in the evening, after having therefore been no less than twelve. hours at least under water. I say at least, because I had no means of knowing how long it had been there before my experiment began. Probably, however, this was about the limit of its endurance; for four other specimens which I treated in the same manner at about 6 o'clock in the evening were apparty dead at the same hour on the following morning, and the individual above mentioned was itself motionless at 9 o'clock, or after fourteen hours of submersion. I then, however, put it in a dry bottle, and next morning it was as lively as ever. Wishing to sce whether it retained any unpleasant recollections of its drowning, I gave it the opportunity of again entering the water, which it immediately proceeded to do.

I was unfortunately unable to ascertain whether they could fly: taking my opportunity when they were out of the water, I teased several specimens of $P$. natans with the point of a needle, but never succeeded in making one take to its wings, at least not in air. When walking on the water, however, they sometimes started off suddenly, but always kept close to the surface, so that it rather seemed as if they were carried by some tiny gust of air.

We might almost wonder how an animal like this, with no apparent weapons of defence, and no great powers of speed, could maintain itself in this world of competition. Protected, however, in its early stages by the victim which it is destroying, it is exposed to its enemies but for a short period of its life; and if, like many of its allies, the eggs of other insects are the prey which it seeks, speed may be of comparatively little importance.

However this may be, we find in the two insects now under consideration no peculiarities indicative of an aquatic life. Many water-insects are more or less boat-shaped, and, both in form and position, the legs are admirably adapted to serve as oars; others, again, use the hinder part of the body as a fish does its tail. Here we find no such arrangements. In both cases the head is broad; in Prestwichia the hind legs have, indeed, some scattered hairs, but not more so than its terrestrial allies; nor in Polynema do the wings appear in any way modified to adapt them to their new function.

Emerson somewhere says, that the population of the world is "not the best, but the best that could live now." Mr. Emerson is no naturalist, or he would surely know that the population of the world at any given time is not the best that can live, but the worst, since it is not the best and strongest, but the worst and weakest which, in the struggle for existence, habitually go to the wall. Thus our two amphibious Hymenoptera, though not so fleet or well armed as they might be, not so long able to respire under water as some other insects, still maintain their existence, because their enemies are unable to destroy them, and they have the field to themselves. 
We have heard much lately about the "imperfection of the Geological Record;" and all geologists admit the fact, though they may differ as to the degree. But what shall we say for the Zoological Record? What terms shall we find strong enough to express our ignorance of existing animals? I speak not now only of foreign species; even in our own country how imperfect is our knowledge even of the Vertebrata! During the last year, two new reptiles and two new fishes have been added to the catalogue; descending to the Invertebrata, however, the case becomes far more striking. Many groups, indeed, have been almost entirely neglected by our naturalists; but, even of those which have been comparatively popular, how little is known! For instance, the Hymenoptera have many admirers, and are carefully studied. Any entomologist happening to see a Hymenopterous insect in the act of swimming would have been well aware that he had a novelty before him; yet the fact that such a creature exists has until now escaped observation. Does not this show how imperfect is our knowledge?

As I have referred to palæontology, permit me to say, in conclusion, that if Polynema natans and Prestwichia aquatica had been extinct species, no palæontologist would have suspected that they were aquatic; in the present state of our knowledge, there is nothing in their structure which would have suggested such an idea.

Mr. Darwin ('Origin of Species,' p. 184) has brought together several instances of the same fact, but not one, I venture to think, which is more remarkable.

Polynema natans, n. $\mathrm{s}$.

Male black.

Female black; legs, eight basal segments of antennæ, posterior part of thorax, and peduncle ferruginous.

Length of female $\cdot 038$ of an inch; of male $\cdot 042$.

In a weedy pond; from the beginning of August to the end of September.

The antennæ are in the male as long as the body, and consist of twelve segments; the basal segment is about twice as large as the others, which do not differ much in size; the second is somewhat pear-shaped; the nine following are cylindrical, abruptly truncated at the apex, tapering at the base; the terminal segment tapers slightly to the apex, which is rounded. They are clothed by short, black hairs, which have somewhat the appearance of being in whorls.

The antennæ of the female are shorter, being only 022 in length. They consist of nine segments; the first two are like those of the male; the following six are smaller and more pear-shaped; the last is rather smaller at the end, and club-shaped. The arrangement of the hairs is the same as in the male.

The anterior legs are of moderate size, and consist of the usual parts. The coxa is broad at its base, and gradually diminishes to the apex; the trochanter is cylindrical; the femur is elongated, and somewhat swollen in the middle; the tibia is long, cylindrical, and increases slightly towards the apex; the tarsus is four-jointed, the two middle segments being somewhat smaller than the first and last. The foot consists of two claws and a central membranous expansion. The hairs on the leg are short, black, and arranged as in other allied species. 
The legs of the second pair are somewhat more elongated, but otherwise very similar; and those of the third pair are decidedly longer, an increase which is not owing to any particular segment.

The legs are not flattened into oars, nor are they provided with fringes as in so many aquatic insects. In fact, this is not to be wondered at, as they are used in walking, and never (as far as my observations went) in swimming.

The wings, though very peculiar, closely resemble those of the other allied species. The anterior pair are as long as the body, and consequently rather longer in the male than in the female; they are between three and four times as long as broad, narrow at the base, gradually expanding for about two-thirds of their length, and rounded off at the apex. They are almost veinless; but at the base, along one margin, there is a thickened portion which is considered to represent the subcostal nerve.

The whole wing is covered by short, simple hairs; and the margin is fringed by long setæ, those in front being, however, shorter than those on the hinder margin, where their length is almost equal to the breadth of the wing.

Through the kindness of Mr. Walker, I have been able to compare my specimens with Polynema pusillus, P.fuscipes, $P$. flavipes, $P$. similis, $P$. atratus, and P. euchariformis, as well as with Mymar longicornis and the very curious $M$. pulchellus.

In the latter species the wing is small, oval, and seated on a long process (see Westwood's Introd. to Modern Classification of Insects, pl. 78. fig. 16). In a specimen which I measured, the wing was .005 of an inch in breadth, and the long setæ were as much as $\cdot 0125$ of an inch in length.

The Polynemas generally have the wings broader, and the setæ rather shorter; thus in Polynema fuscipes, which in many respects has a close resemblance to our species, the length of the wing is $\cdot 05$, the breadth $\cdot 0125$, and the length of the setæ $\cdot 0075$; in other species they are still shorter: but in one labelled "Mymar longicornis," which, however, can hardly, I should think, belong to this genus, the length of the wing is $\cdot 0375$, the breadth $\cdot 00625$, and the length of the setre almost exactly the same. The general structure of the wing is similar also in Oöctonus, Anaphes, and Anagrus. Pl. XXIII. figs. 8 \& 9 represent the fore and hind wings of Anaphes fuscipennis, and it will be seen how closely they resemble those of $P$. natans.

The hind wings (PI. XXIII. fig. 5) are linear, narrow, and situated on a long, slender, chitinous peduncle.

The peduncle has a length of $\cdot 014$ of an inch, the wing itself $\cdot 026$; together $\cdot 04$ of an inch. The wing is attached to the peduncle, not only at the extremity, but also by a narrow strip of membrane, for nearly half its length. It is very narrow, being only .0015 in width; on the surface are one or two small hairs, and the margins are fringed with long setæ.

Similar hind wings occur in Polynema, Anagrus, Anaphes, Oöctonus, and other allied genera. In Litus all four wings are narrow and linear.

Peculiar, therefore, as are the form and structure of the wings, they closely resemble those of other allied species, among which, perhaps, I may particularly mention Anaphes fuscipennis and Anagrus atomus. 
According to the characters which have been regarded by $\mathrm{Mr}$. Walker as of generic value in this group, P. natans would form the type of a new genus. I am, however, unwilling to multiply divisions which perhaps have already been carried too far.

For my second species, however, it seems quite necessary to found a new gonus, which I propose to call Prestwichia, after my friend Mr. Prestwich, one of our most eminent geologists. When this paper was read, I proposed for this species the name of Valkeria. Mr. Busk, however, has pointed out to me that the name was already applied to a genus of Polyzoa*. The generic description, for which I am indebted to Mr. Walker, will stand as follows:-

Genus Prestwichia, n. g.

Fœm. Corpus angustum. Caput transversum. Antennæ graciles, subelavatæ, inarticulatæ; clava longi-fusiformis. Thorax brevis. Abdomen sessile, longi-conicum, subcompressum, thorace plus duplo longius. Oviductus vagina lanceolata, abdominis dimidio longior. Pedes longi, graciles; tarsi 4-articulati; alæ longæ, fimbria longissima; anticæ angustæ, posticæ setiformes.

Female. Body narrow; head transverse, as broad as the thorax. Antennæe slender, subclavate, 10-jointed, as long as the head and the thorax; 1st joint or scape nearly as long as the flagellum; 2 nd, 3rd, 4 th, 5 th, and 6 th joints equal in thickness, successively decreasing in length; 7th fusiform; 8th, 9th, and 10th forming an elongatefusiform club. Thorax short. Abdomen sessile, elongate-conical, slightly compressed, more than twice longer than the thorax. Sheaths of the oviduct lanceolate, more than half the length of the abdomen, proceeding from the tip of the latter. Legs long, slender; tarsi 4-jointed, joints successively decreasing in length; middle legs longer than the fore legs; hind legs stouter and much longer than the middle legs. Fore wings long, narrow, without veins, fringed with hairs which are more than twice longer than the breadth of the wing. Hind wings represented by a filament whose hairs are nearly as long as those of the fore wings.

Prestwichia aquatica, $n$. $\mathbf{s p .}$

Fcem. Nigra; antennis, thorace postico, oviductu pedibusque pallide testaceis; alis anticis cinereis.

Female. Black. Antennæ, hind part of the thorax, sheaths of the oviduct, and legs pale testaceous. Fore wings cinereous, hairs black. Length of the body 05 of an inch; the wings a little longer.

The antennæ are short, being only $\frac{1}{60}$ th of an inch in length. They consist of six or seven segments; the first is long, and near the apex shows a trace of a division. Assuming, from the analogy of Trichogramma evanescens, that this is a true joint, the second segment is short and round. The third is longer, and increases somewhat in size towards the apex; the fourth is similar in shape, but smaller. The rest of the organ

* While this would have been some slight acknowledgment of the numerous ways in which Mr. Walker has put his great knowledge at my disposal, it was certainly no more than a just compliment to one who has so much increased our acquaintance with this department of entomology. 
forms a club-like mass, which appears to be composed of three segments; the last joint, however, is very indistinctly marked.

The legs are much like those of the preceding species; but the fourth segment of the tarsus (Pl. XXIII. fig. 15) is, in all the legs, very small. Mr. Westwood*, indecd, describes the tarsus of his species as being only three-jointed, and in this he is confirmed by Mr. Haliday†. Mr. Westwood's figure, however (fig. 9), shows a fourth segment, which, though small, is even larger in proportion than that of my specics. I am disposed, therefore, to consider that the tarsus of Trichogramma is in reality four-jointed, and that Westwood's and Haliday's descriptions must be amended.

The legs are not compressed, nor have they any fringe of hairs. They show, therefore, no trace of adaptation to their new function.

The anterior wings (Pl. XXIII. fig. 13) are club-shaped, narrow at the base, expanding almost to the apex, with elegantly curved margins. The single nervure extends for about half the length of the wing, and at the apical extremity turns inwards, and ends abruptly. The margin of the wing is fringed by long setæe, which are largest along the club-shaped extremity of the wing, from which they gradually decrease in length in each direction. The insertion of the setæ is somewhat peculiar (Pl. XXIII. fig.13 $a$ ), and makes a pretty border to the wing. Near and parallel to the front and hinder margins are two rows of small spines, and others are scattered about the expanded portion.

The hind wings are narrow, linear, ciliated, situated on a long pedestal, and, in fact, so closely resemble those of Polynema that they need not be separately described.

Remarkable and peculiar as is undoubtedly this conformation of the wings, still, as already observed, it is the same as that which occurs in many allied species, and is not therefore to be regarded as in any way connected with the aquatic habits.

Moreover, we must remember that though the wings of Polynema natans so closely resemble those of Prestwichia, and though both insects are essentially aquatic in their habits, yet the one swims only with its wings, the other with its legs.

While the abdomen of Polynema is petiolated, that of Prestwichia is sessile, and tapers almost from its base to the insertion of the ovipositor; so that the whole body is almost boat-shaped. This latter organ is about as long as the abdomen, very stout in proportion, and bears a few scattered hairs.

My specimens were found in the same pond as $P$.natans, from the beginning of August to the middle of September. It appears, however, to be rarer; and I only found six specimens, all of which were females. Possibly the male is not aquatic in his habits.

* Lond. and Edin. Phil. Mag. 1833, p. 444.

† Ent. Mag. vol. i. p. 341 . 
DESCRIPTION OF THE PLATE.

\section{Plate XXIII.}

Fig. 1. Polynema natans. Side view of female, $\times 30$.

Fig. 2. $" \quad$ Female, seen from above, $\times 30$.

Fig. 3. " $"$ Antenna of female, $\times 60$.

Fig. 4. $\quad, \quad, \quad$ Anterior wing, $\times 60$.

Fig. 5. " " $\quad$ Posterior wing, $\times 60$.

Fig. 6.,$\quad$, Anterior leg, $\times 60$.

Fig. 7.,$\quad$ Posterior leg, $\times 60$.

Fig. 8. Anaphes fuscipennis. Anterior wing, $\times 60$.

Fig. 9. $, \quad, \quad$ Posterior wing, $\times 60$.

Fig. 10. Prestwichia aquatica. Female, seen from above, $\times 30$.

Fig. 11. " " $"$ side view, $\times 30$.

Fig. 12. , , Antenna, $\times 30$.

Fig. 13.,$\quad$ Anterior wing, $\times 60$.

Fig. 14. " $\quad$ Posterior leg, $\times 60$.

Fig. 15. " " $\quad$ Tarsus of ditto, $\times 250$. 


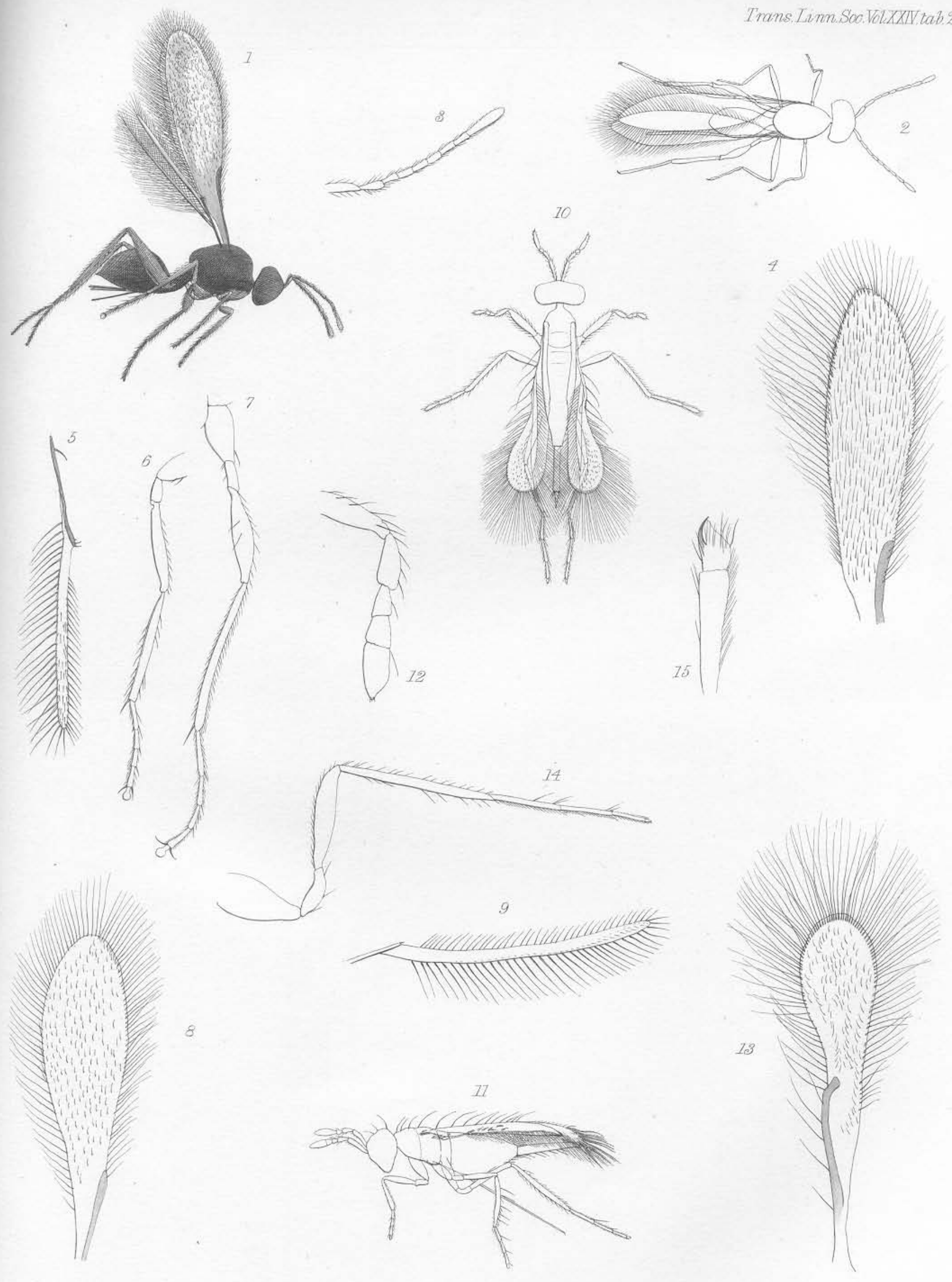

Jubbock del. 